\title{
Archaeological Testing of Proposed Sewer Line Location at Mission San Jose
}

David Hafernik

Anne A. Fox

Follow this and additional works at: https://scholarworks.sfasu.edu/ita

Part of the American Material Culture Commons, Archaeological Anthropology Commons, Environmental Studies Commons, Other American Studies Commons, Other Arts and Humanities Commons, Other History of Art, Architecture, and Archaeology Commons, and the United States History Commons

Tell us how this article helped you.

This Article is brought to you for free and open access by the Center for Regional Heritage Research at SFA ScholarWorks. It has been accepted for inclusion in Index of Texas Archaeology: Open Access Gray Literature from the Lone Star State by an authorized editor of SFA ScholarWorks. For more information, please contact cdsscholarworks@sfasu.edu. 


\section{Archaeological Testing of Proposed Sewer Line Location at Mission San Jose}

Creative Commons License

(c) (i) (8)

This work is licensed under a Creative Commons Attribution-NonCommercial 4.0 International License 


\section{archaEOLOGICAL testing of proposed SEWER LINE LOCATION AT MISSION SAN JOSE}

DAVID HAFERNIK AND ANNE A. FOX

Center for Archaeological Research

The University of Texas at San Antonio

Archaeological Survey Report, No. 138

1984 



\section{ARCHAEOLOGICAL TESTING OF PROPOSED \\ SEWER LINE LOCATION AT \\ MISSION SAN JOSE}

David Hafernik and Anne A. Fox

Investigations conducted under

Texas Antiquities Committee Permit No. 411

Submitted to a Joint Venture of Consulting Engineers 9310 Broadway, San Antonio, Texas 78217

Center for Archaeological Research The University of Texas at San Antonio Archaeological Survey Report, No. 138 
The following information is provided in accordance with General Rules of Practice and Procedure Chapter 41.11 (Investigation Reports), Texas Antiquities Committee:

1. Type of investigation: Archaeological investigations and testing at Mission San José;

2. Project name: Archaeological Testing at Mission San José, San Antonic 201 Wastewater Facilities Improvements Project;

3. County: Bexar County, Texas;

4. Principal Investigator: Thomas R. Hester; Co-Principal Investigator: Anne A. Fox;

5. Name and 1ocation of sponsoring agency: A Joint Venture of Consulting Engineers, 9310 Broadway, San Antonio, Texas 78217

6. Texas Antiquities Committee Permit No. 411;

7. Published by the Center for Archaeological Research, The University of Texas at San Antonio, San Antonio, Texas 78285, 1984.

A 1 ist of publications offered by the Center for Archaeological Research can be obtained by sending $\$ 1.00$ to the Center for Archaeological Research, The University of Texas at San Antonio, San Antonio, Texas 78285. 


\section{ABSTRACT}

In April 1984 archaeologists from the Center for Archaeological Research, The University of Texas at San Antonio, excavated a backhoe trench outside the west wal1 of Mission San José. The purpose of the investigation was to determine if a proposed sewer 1 ine for the San Antonio 201 Wastewater Facilities Improvements Project would affect any major historic or prehistoric resources. A stone-1ined we 11 was found that was constructed sometime after the secularization of the mission in 1893 and continued in use, first as a wel1 and 1 ater as a privy pit, until ca. 1940. Because of the likelihood of stratified deposits of 19th-century artifacts within the well fill, the site is recommended for archaeological excavation. 


\section{TABLE OF CONTENTS}

ABSTRACT . . . . . . . . . . . . . . . . . . . . . . .

LIST OF FIGURES . . . . . . . . . . . . . . . . . . . . . . i i

LIST OF TABLES . . . . . . . . . . . . . . . . . . . . . . . i i

INTRODUCTION . . . . . . . . . . . . . . . . . . . . . . 1

HISTORY OF THE SITE . . . . . . . . . . . . . . . . . . . 5

PREVIOUS ARCHAEOLOGY . . . . . . . . . . . . . . . . . . 5

TESTING . . . . . . . . . . . . . . . . . . . 5

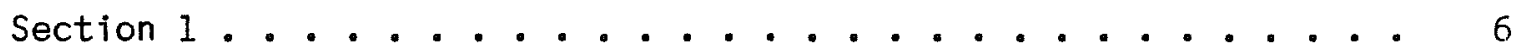

Section 2.............................. 6

Section 3.............................. 8

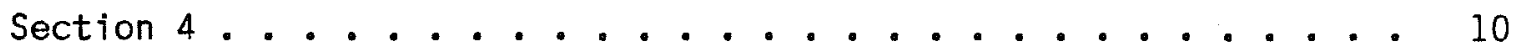

Section 5.......................... 10

THE ARTIFACTS . . . . . . . . . . . . . . . 10

CONCLUSIONS AND RECOMMENDATIONS .................... 11

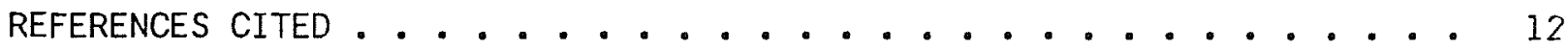

\section{LIST OF FIGURES}

1. Intracity Location Map . . . . . . . . . . . . . . . 2

2. Trench Location Map .. . . . . . . . . . . . . . 3

3. Undated Aerial Photograph of Mission San José

Looking North-Northeast ca. 1931-1932 . . . . . . . . . . . . 4

4. Plan and Profile of Well . . . . . . . . . . . . . . 9

\section{LIST OF TABLES}

1. Artifact Provenience .................. . . 7 


\section{INTRODUCTION}

Under the terms and conditions of the existing 1976 Professional Services Contract between A Joint Venture of Consulting Engineers and the Center for Archaeological Research (CAR). The University of Texas at San Antonio (UTSA), work was continued on the San Antonio 201 Wastewater Facilities Improvements Project in April 1984. The project is regulated and permitted by the Environmental Protection Agency. This stage of the project was located outside the west wall of Mission San José y San Miguel de Aguayo on Roosevelt Avenue (State Highway 281) on the south side of San Antonio (Fig. 1). The purpose of the investigation was to determine if the proposed placement of a sewer 1 ine in the area would affect any significant historic or prehistoric. resources. The trench for the sewer 1 ine would be approximately 10 feet wide, and the 1 imit of the construction area would be the boundary between the National Park and the right-of-way for Highway 281; the trench was to be located between that 7 ine and the curb (Fig. 2).

In order to determine what archaeological features, if any, would be encountered by the proposed sewer line, it was decided that a backhoe trench would be excavated along the route of the line within the highway right-ofway. The depth of the trench would be determined by the depth of evidence of human occupation. Archaeologists would monitor the excavation, collect diagnostic artifacts found during trenching, and record all features encountered.

On April 24 and 25, 1984, an archaeological field crew under the supervision of Anne A. Fox, Research Associate with the Center for Archaeological Research, conducted subsurface testing at Mission San José. The testing consisted of the placement of a backhoe trench along the route of the proposed sewer line (Fig. 3). The field crew consisted of Roger Johnson and Ralph Snavely, graduate students in Anthropology at The University of Texas at San Antonio. Al1 work was done under the general supervision of Principal Investigator, Dr. Thomas R. Hester, Center Director, and Co-Principal Investigator, Anne A. Fox. The artifacts recovered, as well as the field notes and records from the project are on file in the 1 aboratory of the Center for Archaeological Research. The study was done under Texas Antiquities Committee Permit No. 411 and complies with the National Environmenta 1 Policy Act of 1969.

Mission San José y San Miguel de Aguayo is on the National Register of Historic Places and is a State Archeological Landmark. It is also included within the San Antonio Missions National Historic Park, administered by the National Park Service. The site carries the state designation 41 BX 3 .

Since the National Register application merely lists Roosevelt Avenue as the eastern edge of the site, we infer that the backhoe trench 1 ies within the National Register site. The State Archeological Landmark designation includes on $1 y$ the 1 ands previous 1 y owned by the Texas Parks and Wild 1 ife Lepartment, which could conceivabiy mean that the backhoe trench is not. within the Landmark itself. In any case, we believe that the area under investigation is an integral part of the mission, lying as it does within, and immediately adjacent to, the properties partitioned off at the time of 


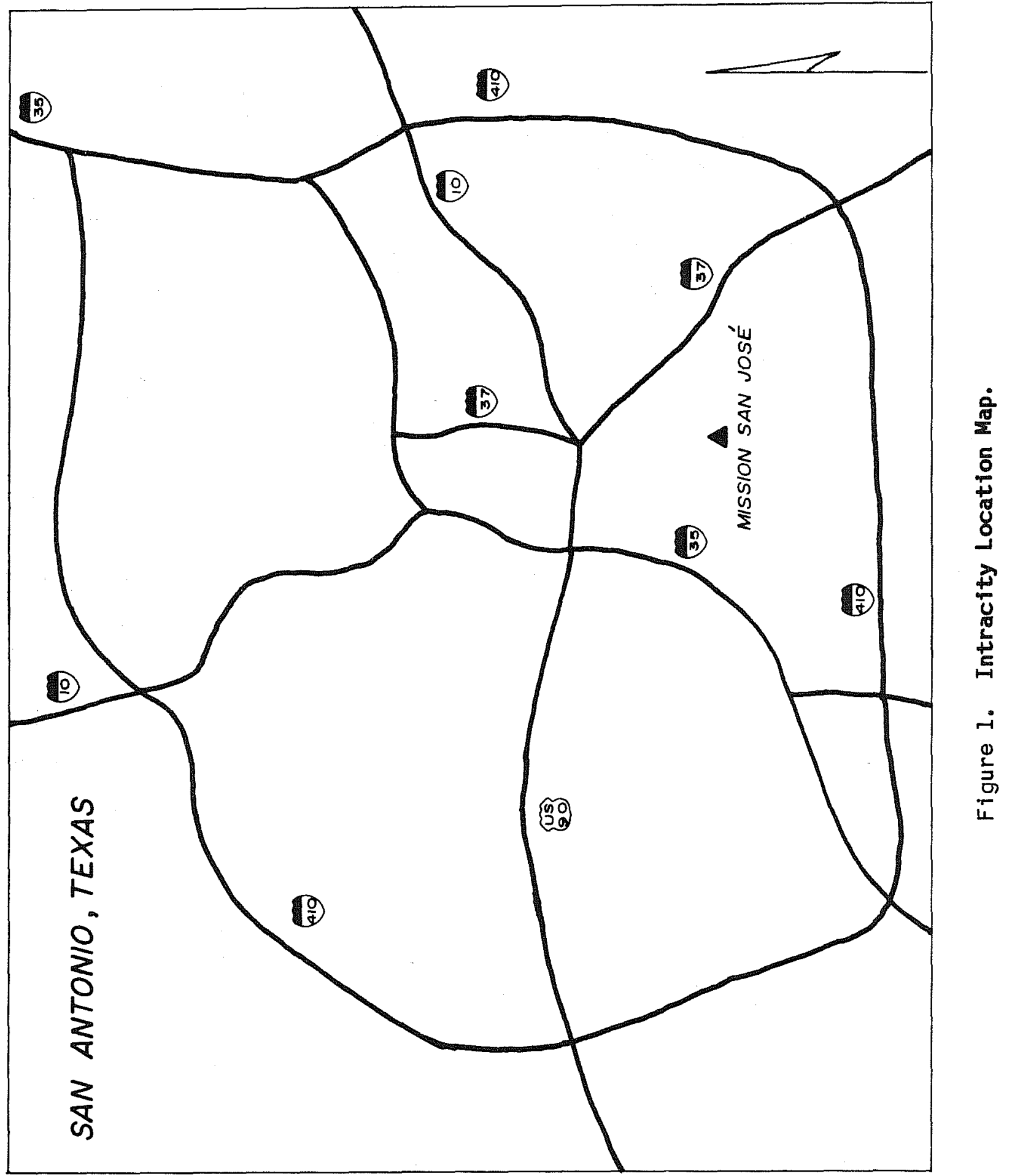




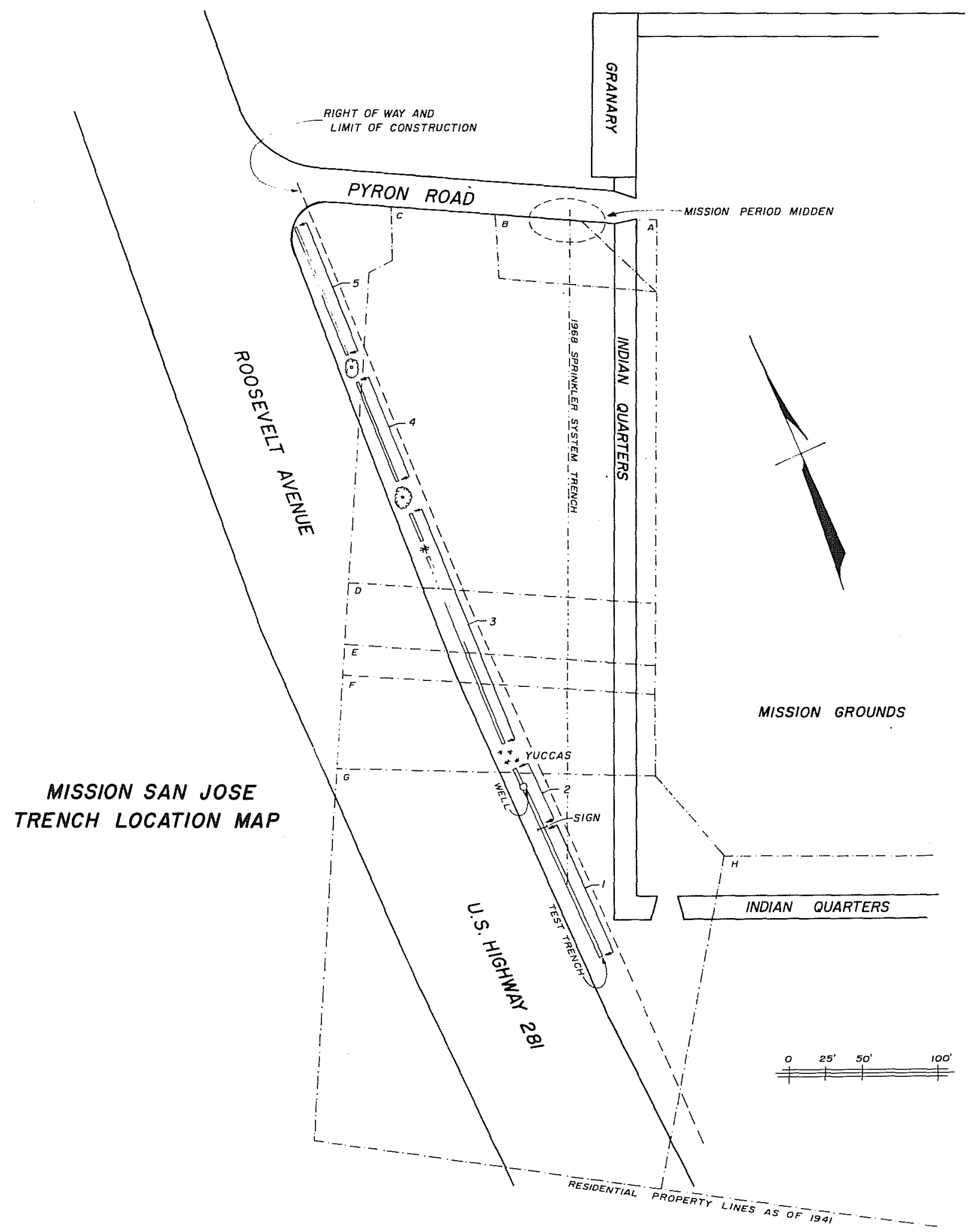

Figure 2. Trench Location Map. Landowners as of 1941 are as follows: $A, G_{0}$ Huizar; B, Ignacio Saucedo; C, Martina Escalera de Huizar; D,Elena T. Vanegas; E,Gregorio Vallejo; F,Filipe Guerrero; G,Mrs. Rosa H. Schelcher; H,Catarina Guerrero (Map of Land Ownership ca. 1940). 


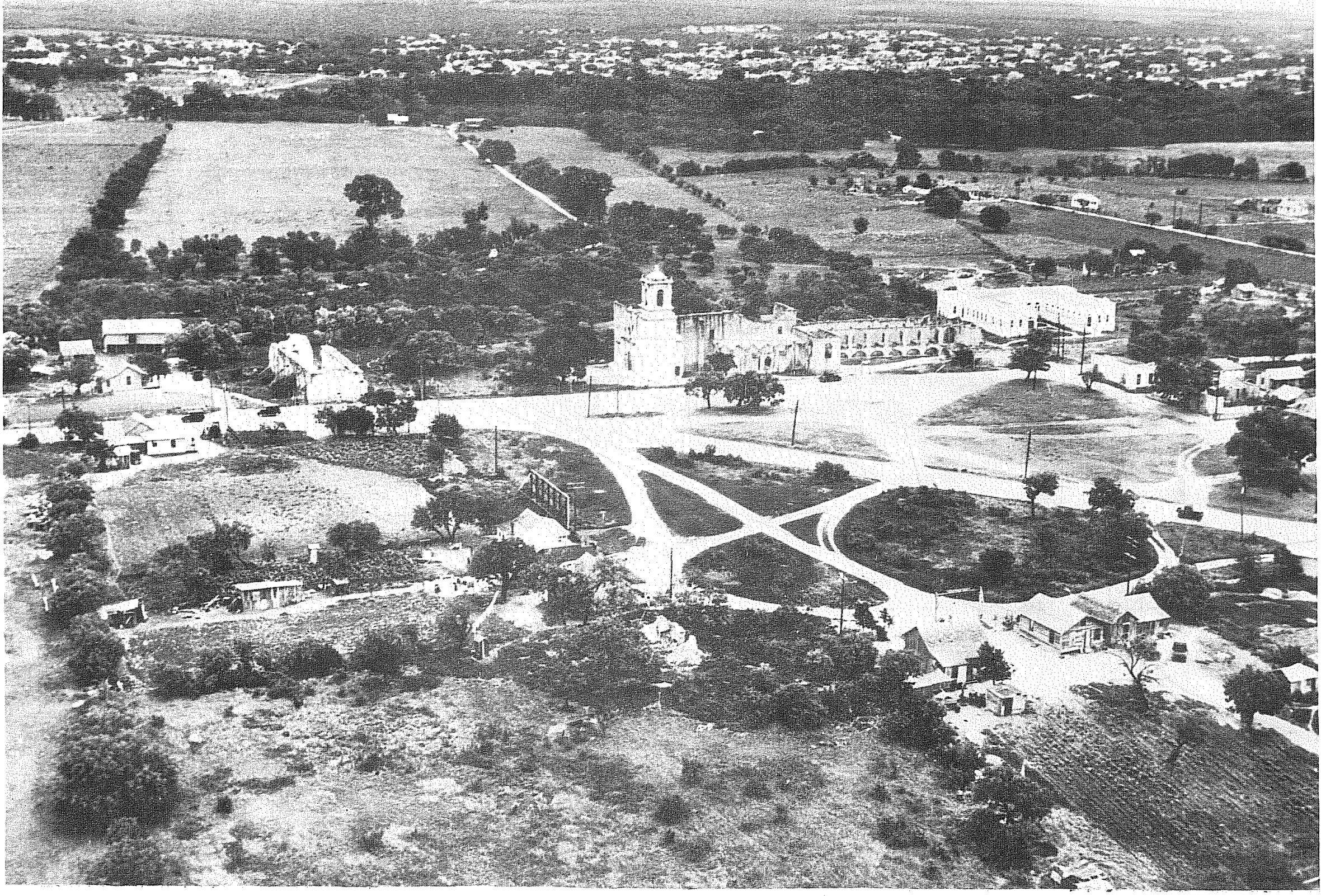

Figure 3. Undated Aerial Photograph of Mission San José Looking North-Northeast ca. 1931-1932. From the files of the San Antonio Missions National Historic Park. Note Schelcher property outlined by trees in lower left quadrant, and privy near the north lot line. For location of backhoe trench, compare with Figure 2. 
secularization and directly related to the 1 ives of those persons who 7 ater purchased or inherited those 1 ands.

\section{HISTORY OF THE SITE}

The general area has been continuously occupied from the 1740 s when Mission San José was moved to the site (Habig 1968:45) to the 1940s when reconstruction of the mission began. The property was divided into 1 ong, narrow strips running perpendicular to the mission walls at the time of secularization in 1893, and at that time was acquired by various mission Indian families and local Spanish citizens. At first the people 1 ived in the stone buildings on the mission wal1s. These buildings were gradual1y modified or replaced by smal1 frame houses, at which time the area to be impacted by the sewer trench would have been in the back yards of these houses and could possibly have been the location of wel1s, trash dumps, or other features related to these houses. By 1931-1932 (Fig. 3) much of the 1 and had fallen vacant, some ruins of the stone houses remained, and a few frame houses continued to be occupied. Fence 1 ines visible in the area reflect property 1 ines found on a 1941 map in the National Park Service collections (see Fig. 3 ).

From the time of the restoration of the mission, the area through which the test trench was excavated has been unoccupied parkland. Rooseve1t Avenue was cut through the area ca. 1934. Although the newly reconstructed mission buildings were occupied by various craftsmen and others connected with mission operations in the 1940s, the absence of openings to the outside of the compound in this section of the wal1 prevented use of the area outside the wal1 by the residents.

\section{PREVIOUS ARCHAEOLOGY}

Although a number of archaeological investigations have been done at Mission San José (Schuetz 1970; Fox 1970; Clark 1978; C1ark and Prewitt 1979), the only work in this particular area was monitoring of excavation of trenches for a sprinkler system in 1968 (Schuetz 1970). No architectural features, we11, cisterns, or trash dumps were found in the area crossed by the sprinkler trench that ran parallel to the west wa 11 and approximately 30 feet from it, with the exception of a mission trash dump located just outside the west gate. The area encompassed by this dump was some distance from the 1 ine of the proposed sewer trench (Fig. 2).

\section{TESTING}

In order to obtain as much detailed information as possible, the test trench was excavated in 19 sections. The artifacts from each section were recorded and catalogued individualiy. Once in the laboratory it was decided that the trench best lent itself to division into five major sections, and the artifacts were then grouped accordingly. The artifacts were catalogued, however, in the orisinal groups so that provenience could be maintained. 


\section{Section 1}

Section 1 of the excavation began at the south end of the area in question and extended 94 feet in a northward direction at a depth of approximately three feet and a width of two feet six inches. The section of trench was located on the property of Mrs. Rosa. Schelcher as of 1941 (Fig. 2).

In Section 1 there was a layer of topsoil approximately seven inches deep, consisting of brown soil and gravels. Very few artifacts were recovered from this level. An occupation level of approximately six inches in depth was located below the topsoil. Below the occupation level the remaining 23 inches consisted of hard-packed, red brown, sterile soil containing a high percentage of clay. This pattern of deposits remained relatively consistent throughout the section.

For purposes of analysis and to obtain a more accurate representation of the area, Section 1 of the trench has been divided into Subsections $1 A$ and $1 B$. Subsection $1 A$ includes the first three recorded excavation units, while Subsection IB consists of the next three units.

Subsection IA encompassed the first 45 feet of the trench. This section had a 1 arge variety but comparatively small number of artifacts (Table 1). The variety of artifacts reflects the long occupation period of the mission. The largest assortment of early 19th-century decorated earthenwares was found in this section of the trench. A variety of colored glass fragments and several items associated with construction were recovered. Several artifacts associated with household use were recovered. These items included tin can fragments, metal utensil fragments, and bottle caps.

Subsection $1 B$ contained the remaining 49 feet of the first section, ending a few feet short of the park sign. This section had a slightly smaller variety, but a much larger number, of artifacts than Subsection IA. A smaller selection of early 19th-century artifacts, the majority from the post-Civil War period and later, was recovered from Subsection 1B. All of the types of ceramics found in this section were also found in Subsection $1 A^{\text {. }}$ This section, however, contained a larger variety of colored glass fragments. Additionally Subsection $1 B$ contained artifacts associated with a barn or shop: horse equipment, a pulley, an axe head, and a machine part. The types and variety of artifacts recovered in these two sections suggest that this area was used for trash disposal.

\section{Section 2}

Section 2 of the trench began north of the park sign and continued 41 feet 6 inches north at a depth of approximately three feet and a width of two feet eight inches. The trench still lay for the most part within the property of Mrs. Schelcher, however, the last eight feet were on the property of Felipe Guerrero (Fig. 2).

The soil in Section 2 changed at about 10 inches in depth from a loosely packed brown soi 1 to a thin 1 ayer of fine gravel two to four inches thick. The following level was a mix of 100 sely packed gray brown soil. This 
TABLE 1. ARTIFACT PROVENIENCE

$\begin{array}{llllll}\text { SECTIONS } & 1 & 2 & 3 & 4 & 5\end{array}$

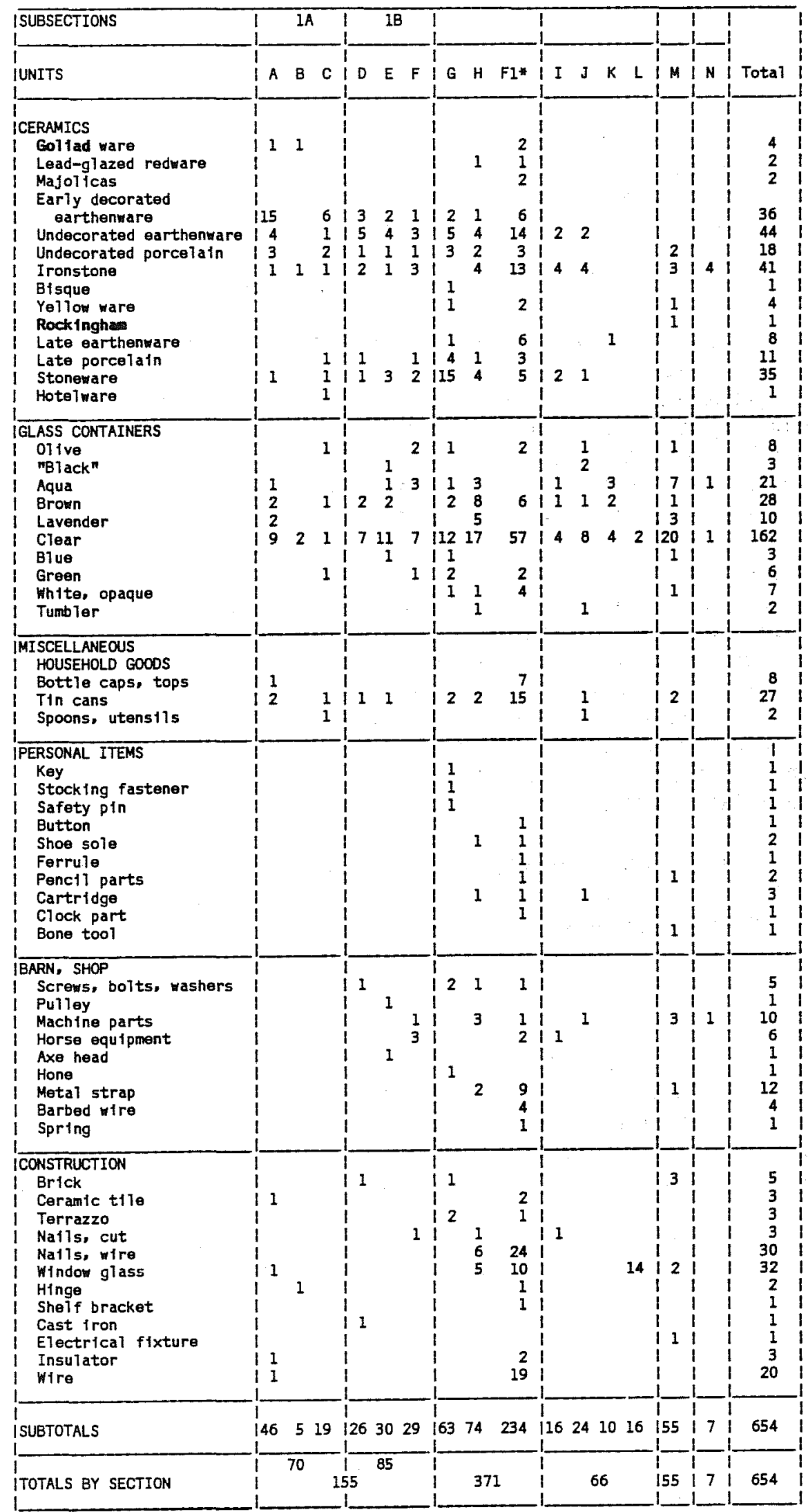

*Feature 1 is from Section $2 \mathrm{H}$. 
continued to a depth of approximately 24 inches. The profile remained relatively consistent for the length of the section.

At 25 feet 6 inches from the park sign, a 1 1/2-inch iron pipe was located running east-west at a depth of 10 inches. The pipe was 1ocated directly above a row of stones which also ran across the trench at a depth of 16 inches below the ground surface. Another similar row of stones was found five feet six inches to the north ( $F i g .4$ ), and the area between was fil ied with loose soil containing ash, charcoa1, and artifacts. The walls were determined to be the edges of a we 11. Excavation within the structure was carried only to a depth of 30 inches below the ground surface. This well was located at the north end of Mrs. Schelcher's property. According to an early photograph, a privy was located over the well in the 1930 s (Fig. 3). This custom of using an abandoned well for a privy pit has been noted by archaeologists in Alexandria, Virginia (Cressey et a 1. 1982:156) and could be considered a practical solution to the problems of filling an abandoned we 11 and creating a pit for the family privy. When the privy was removed, apparent1y the remaining depression was used as a trash pit, then covered with fill when the park was created.

Most of the artifacts in this section of the trench were located just above, in, or just below the layer of grave1, or within the wal1s of the we11. A large variety of ceramics was recovered, including early decorated earthenwares, undecorated porcelains, ironstone, stoneware, late earthenwares, and late porcelain (Table 1). Several types of colored glass were also recovered, including clear, brown, aqua, olive, and white. This section also contained the largest variety of personal items found throughout the trench. Items associated with operation of a barn or shop as we 11 as items associated with construction were also found.

The large number and variety of artifacts recovered from this section he1p support the idea that once the well was no longer supplying water, it was used for trash disposal.

\section{Section 3}

Section 3 of the trench began 15 feet north of the termination of Section 2, due to an obstruction formed by a large bed of ornamental yuccas and cacti. This section extended 165 feet north at a depth of three feet. It began on the property of Felipe Guerrero and continued across the properties of Gregorio Vallejo, Elena Vanegas, and Martina Escalera de Huizar (Fig. 2).

Soil in this area seemed uniformly chocolate brown, grading to a redder tinge at about three feet. The change in color is caused by the inclusion of smal1 fragments of a white caliche 1 ike material and numerous sma 11 snail she 11 fragments in the lower section. The profile remained consistent throughout the section.

Artifacts recovered in this section (see Table 1) reflect a later period of occupation. Of the ceramics recovered, there was one piece of early decorated earthenware and several later pieces of earthenware, ironstone, and stoneware. Glass was the most commonly recovered artifact in this section, 


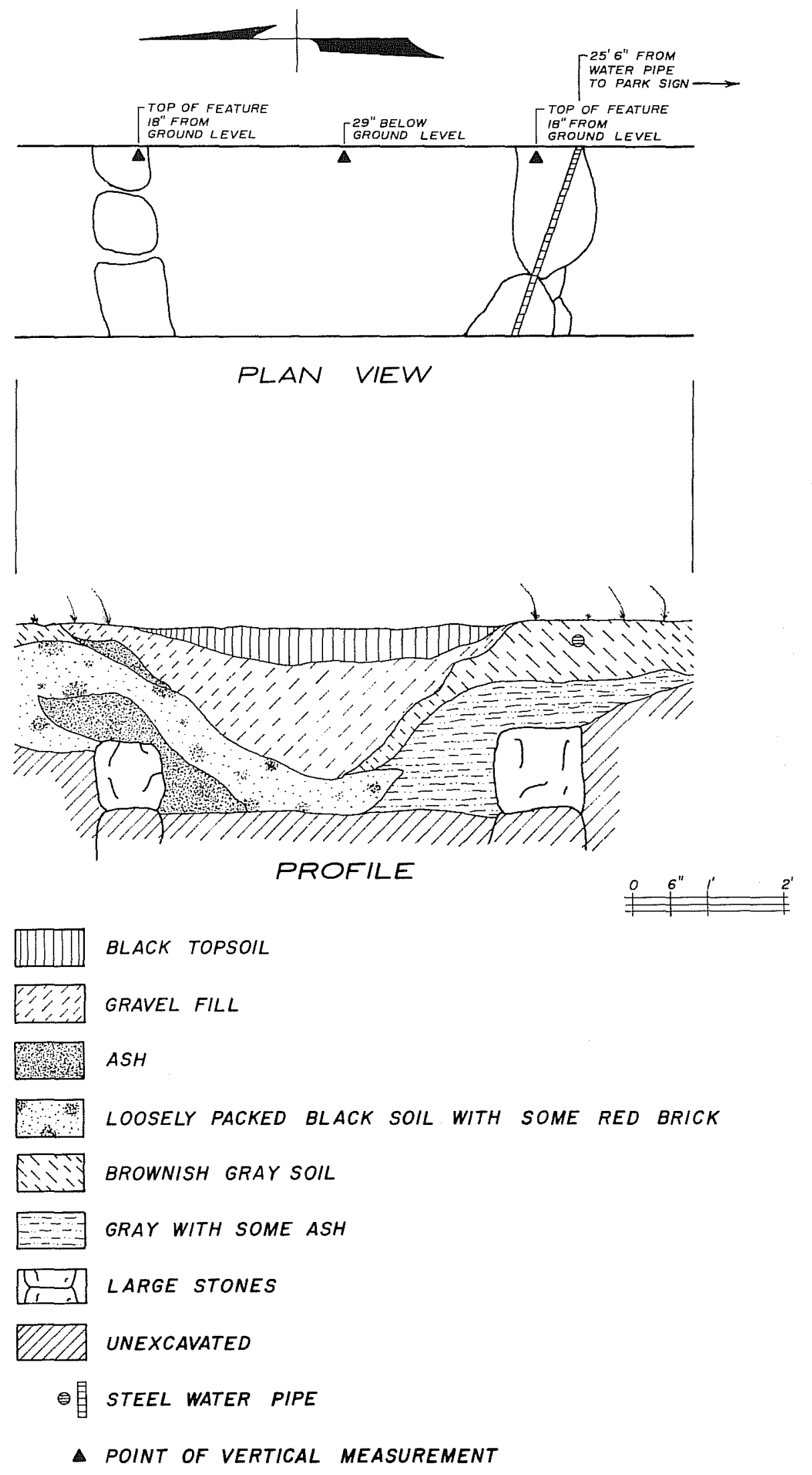

Figure 4. Plan and Profile of Well. 
including a number of sherds of window glass. Of interest were fragments of a glass tumbler, a silver-plated spoon, tin can fragments, and a cartridge casing. A few artifacts associated with a barn or shop were also recovered: an iron ring, a heavy metal handle, and a cut nail. Fewer artifacts were recovered throughout Section 3 of the trench, suggesting that the area was too far from the back doors of the houses on the wall 1 ine to be used for trash disposal.

\section{Section 4}

Section 4 of the trench began about 30 feet north of the end of Section 3 due to the presence of a large mesquite tree on the 1 ine of the trench, and extended north 67 feet. This section of the trench 1 ay, for the most part, on the property of Martina Escalera de Huizar, but extended an additional five to eight feet beyond the back line of her lot (Fig. 2).

The soil in this section appeared to be a continuation of the soil found in Section 3. A one-inch iron pipe was found 35 feet 6 inches from the south end of the trench section, running east-west. At 44 feet a circular ash lense was uncovered at 32 inches below the surface. It was approximately 30 inches in diameter and five inches thick. The soil below the feature was reddened as if heated by a fire, suggesting that this was the location of a small back yard activity of some sort. The deposit consisted of ash and charcoal, with no artifacts in direct association.

The number of artifacts recovered during trenching continued to decrease throughout the section, and reflected the later period of occupation in the area. Various colors of glass, brick fragments, fragments of a porcelain cup, tin can fragments, machine parts, and a porcelain electrical fixture were found in this section.

\section{Section 5}

Section 5 encompassed the 1 ast 88 feet of the area, extending from the drip line of a large huisache tree to the curb 1 ine of Pyron Avenue which once ran through the mission. At 66 feet a pipeline was located on a direct 1 ine with the trench, which necessitated moving the trench eight feet to the east of the original trench 1 ine. Dense gravel approximately 14 inches in depth covered by six inches of topsoil was encountered, indicating that this section ran through the original roadbed. Few artifacts were recovered in this section (Table 1).

\section{THE ARTIFACTS}

The artifacts recovered during the backhoe trenching reflect the entire 200year period of occupation of the site, from the 1740 s to the 1940s. The artifacts have been divided into six categories according to their probable usage (see Table 1). These categories include ceramics, glass containers, miscellaneous household goods, personal items, barn or shop items, and items used in construction. None of the artifacts recovered differed substantially 
from those described and 117 ustrated numerous times in previous reports on archaeology at Mission San José (Schuetz 1970; Fox 1970; C1ark 1978; C1ark and Prewitt 1979) and elsewhere in San Antonio.

Ceramics are the most useful artifact category for dating an archaeological deposit. due to the regularity with which new types were introduced and older types were abandoned, plus changes in points of origin reflecting historic and economic changes. We use them, therefore, to indicate general time periods represented by the artifacts recovered from the trench. Missionrelated deposits are represented by Goliad ware, a local1y made, low-fired earthenware; lead-glazed redwares; and tin-glazed majolicas imported from Mexico during the Spanish Colonial period. Early decorated and undecorated earthenwares and porcelain represent the first half of the 19th century in San Antonio. Ironstone, earthenwares, and porcelains with decal designs, and stoneware represent the time period from the Civil War to the early 20 th century.

As might be expected, mission period artifacts were found only at the south end of the trench where it approaches the mission wal1. It is also interesting that a few of these wares were found in the upper level of the wel1 deposits. These could represent inclusions in fill brought in at a 1 ater time to level the feature. Early 19th-century ceramics were common in the first two sections of the trench with the number faling off rapidiy from that point on north.

\section{CONCLUSIONS AND RECOMMENDATIONS}

Archaeological testing by means of a backhoe trench was conducted on the western boundary of Mission San José during April 1984. The artifacts recovered represented the ful1 200-year occupation of the site.

A stone-1 ined we 11 approximately five feet in diameter was uncovered and recorded. No information is available on the date of construction or the possible contents of the we11. However, there is a possibility that it may contain artifacts dating from 1800 to the 1940 s. Information from a stratified deposit of this nature could be of inestimable value in confirming artifact dates for the 19th century. In addition, important information on the $1 \mathrm{ife}$ and ethnic background of the 1ocal inhabitants could also be recovered from the well fill. We therefore believe this makes the we 11 potential 1 y eligible for nomination to the National Register of Historic Places, and since it 1 ies with in the right-of-way for Highway 281, it would also be potentially eligible to be designated a State Archeological Landmark.

Since it appears that the proposed sewer trench wil1 have to impact the we11, we recommend that mitigation in the form of archaeological excavation of the contents of the wel1 be done before the excavation of the sewer trench. 


\section{REFERENCES CITED}

Clark, J.

1978 Mission San Josë y San Miguel de Aguayo: Archeological Investigations, December 1974. Texas Historical Commission, Office of the State Archeologist, Report 29.

Clark, J. and E. Prewitt

1979 Archeological Test Excavations in an Area to be Affected by a Proposed Trench Drain West of the Granary. Mission San Jose State Historic Site (4l BX 3), Bexar County, Texas. Prewitt and Associates, Inc., Report of Investigations 3.

Cressey, P. J., J. F. Stephens, S. J. Shephard, and B. H. Magid

1982 The Core-Periphery Relationship and the Archaeological Record in A lexandria, Virginia. In Archaeology of Urban America, edited by Roy S. Dickens, Jr. Academic Press, New York.

Fox, D. E.

1970 Archeological Salvage at Mission San José, December 1969, April and August 1970. Texas Historical Survey Committee.

Habig, Fr. M. A.

1968 San Antonio's Mission San José, State and National Historic Site 1720-1968. The Naylor Company, San Antonio.

Map of Land Ownership

ca. 1940 Map in files of San Antonio Missions National Historic Park.

Schuetz, M. K.

1970 Excavation of a Section of the Acequia Madre in Bexar County: Texas, and Archaeological Investigations at Mission San José in Apri1, 1968. Texas Historical Survey Committee, Archaeological Report 19. 